\title{
INTERNATIONAL RESEARCH JOURNAL OF PHARIMACY
}

\author{
www.irjponline.com
}

ISSN $2230-8407$

\section{Research Article}

\section{PRELIMINARY STUDIES OF SOME MARKETED AYURVEDIC PREPARATIONS OF ASAVA'S AND ARISHTA'S}

Mohini Kuchekar $^{1 *}$, Mohini Upadhye ${ }^{2}$, Ashwini Chakor ${ }^{2}$

${ }^{1}$ Department of Pharmacognosy, P. E. S's Modern College of Pharmacy, Savitribai Phule Pune University Ganeshkhind, Pune, Maharashtra, India

${ }^{2}$ Department of Pharmacognosy, P. E. S's Modern College of Pharmacy (For Ladies), Savitribai Phule Pune University Ganeshkhind, Pune, Maharashtra, India

*Corresponding Author Email: phanse_mohini@yahoo.co.in

Article Received on: 18/07/17 Approved for publication: 10/08/17

DOI: $10.7897 / 2230-8407.088138$

\section{ABSTRACT}

Ayurveda is a science of life. Ayurveda is considered as the Upaveda of Atharvaveda which deals with different type of herbs, plants, the anatomy and physiology of different organs of body and the principles of treatment of diseases. Ayurveda is an oldest system of medicine which native to India. Asava and Arishta's are liquid preparations containing self generated alcohol. Thus contain water soluble as well as alcohol soluble substances of the drugs. Asava and Arishta's are differing from each other owing to their difference in method of preparation. In the current study, an attempt was made to evaluate some ayurvedic preparations like Asava and arishta available in market. The preparations were evaluated for various parameters like estimation of alcohol content, $\mathrm{P}^{\mathrm{H}}$ values, total solid content, density, surface tension and viscosity of Asava and Arishta's. It was observed that an establishing quality and standard parameters like alcohol level, $\mathrm{P}^{\mathrm{H}}$, acid values and other components of all these preparations are highly significant.

Key words: Asava, Arishta's, Marketed Preparations, Evaluation study.

\section{INTRODUCTION}

Ayurveda is one of the most ancient systems of medicine known today developed through daily life experiences with the mutual relationship between mankind and nature ${ }^{1}$.

The lack of appropriate clinical studies of Ayurvedic treatments is heavily criticized by Western physicians. Western physicians and medical scientists claim that very few clinical studies exist and those that do exist show, at best, questionable results. Their main concern against Ayurveda is that its reliance on pure observation, experimentation, and philosophical emphasis on individualizing treatments (i.e. making different treatments for different people for the same disease) create consistency and unreliable data on the efficacy of the treatments. Although Ayurved as strength comes from the fact that it is highly individualized form of medicine, this is a disadvantage in the context of the western world ${ }^{2,3,4}$.

This traditional system comprises of various types of medicines including fermented forms, namely Asavas and Arishta's. Fermented dosage forms show high palatability and stability ${ }^{5}$.

Asava and arishta have been used as medicines for over 3000years to treat various disorders and are also taken as appetizers and stimulants. Asava and Arishta's are liquid preparations containing self generated alcohol. Thus contain water soluble as well as alcohol soluble substances of the drugs. Asava and Arishta's were differing each other owing to their difference in method of preparation ${ }^{6}$.
In the current study, an attempt was made to evaluate some marketed Ayurvedic preparations of Asava and arishta for the estimation of alcohol content, $\mathrm{P}^{\mathrm{H}}$ values, total solid content, surface tension and viscosity.

\section{MATERIALS AND METHODS}

Collection of samples: All the sample preparations of Asavas and arishta were purchased from local market Pune. The details of Ayurvedic preparations were given in Table 1.

\section{Preliminary evaluation}

All Preparations of Asava and Arishta's were evaluated for their preliminary evaluations study ${ }^{7,8}$. This study involves identification of odour, taste and colour. The results have been shown in Table 2.

\section{Determination of alcohol content}

The deviation in ethanol content in ayurvedic preparations like Asava and Arishta's were stand a critical difficulty to fix their limits as a quality control parameter. By considering this approach to set up its limit over a period of time, the present study was focused on determination of ethanol content of the preparations 9 .

For the estimation of alcohol content, $100 \mathrm{ml}$ of each preparation of Asava and Arishta's were distilled at temperature $78.5^{\circ} \mathrm{C}$ until content volume was obtained. The yield was calculated as percentage weight by $\mathrm{ml}$ basis. The distillations were repeated another two times for each preparation. Values were represented as means of \pm S.D for there trails. 
Table 1: Preparations of Asava and Arishta purchased from the market

\begin{tabular}{|c|c|c|c|c|}
\hline $\begin{array}{l}\text { Sr } \\
\text { no }\end{array}$ & $\begin{array}{l}\text { Preparation name and } \\
\text { company }\end{array}$ & $\begin{array}{l}\text { Net volume } \\
(\mathrm{ml})\end{array}$ & Main ingredient & Uses \\
\hline 1. & $\begin{array}{l}\text { Ushirasav (Sandu brothers } \\
\text { Pvt Ltd, Mumbai) }\end{array}$ & $200 \mathrm{ml}$ & $\begin{array}{l}\text { Ushira, Balaka, Padma, } \\
\text { Gambhari, Patha, Priyangu, Dhataki, } \\
\text { Nilotpala, Padmaka, Shati, etc. }\end{array}$ & Raktpitta, anaemia, piles, skin disorder. \\
\hline 2. & $\begin{array}{l}\text { Vasakasava } \quad \text { (Sandu } \\
\text { brothers Pvt Ltd, Mumbai) }\end{array}$ & $200 \mathrm{ml}$ & $\begin{array}{l}\text { Vasaka, Guda, Dhataki, Tvak, } \\
\text { Tejapatra, }\end{array}$ & Kas, kshya, raktapitta. \\
\hline \multirow[t]{2}{*}{3.} & $\begin{array}{l}\text { Punarnaasava } \quad \text { Sandu } \\
\text { pharmaceuticals Ltd, Navi } \\
\text { Mumbai) }\end{array}$ & $200 \mathrm{ml}$ & $\begin{array}{l}\text { Shunthi, Marich, Pippali, Haritaki, } \\
\text { Bibhitaka, Darvi, Brihati, Kantakari, Vasa, } \\
\text { Mula, Eranda Mula, Kataki etc. }\end{array}$ & $\begin{array}{l}\text { Oedema, hyperacidity, udar rog, disorder } \\
\text { of yakrit, and spleen. }\end{array}$ \\
\hline & $\begin{array}{l}\text { Ashokarishta } \\
\text { (Shree baidynath } \\
\text { Ayuredav, bhavan, Pvt } \\
\text { Ltd) }\end{array}$ & $200 \mathrm{ml}$ & $\begin{array}{l}\text { Ashoka, Guda, Dhataki, Ajaji, Musta, } \\
\text { Sunthi, Daruharidra, Utpala, Haritaki, } \\
\text { Bibhitaka, Amalaki, Vasa etc. }\end{array}$ & $\begin{array}{l}\text { Excellent, tonic for women. Relieves } \\
\text { backache, stomach, headache, debility. }\end{array}$ \\
\hline 5. & $\begin{array}{l}\text { Khdirarishta } \\
\text { (Shree baidynath Ayurveda } \\
\text { bhavan Pvt Ltd) }\end{array}$ & $200 \mathrm{ml}$ & -- & $\begin{array}{l}\text { Indicated in all types of skin, diseases } \\
\text { and problem associated with it like } \\
\text { inflammation, itching, rases, minor } \\
\text { boiles etc. }\end{array}$ \\
\hline 6. & $\begin{array}{l}\text { Dashmularishta } \\
\text { brothers Pvt Ltd) }\end{array}$ & $200 \mathrm{ml}$ & $\begin{array}{l}\text { Bilva, Syonaka, Gambhari, Patala, } \\
\text { Agnimantha, Salaparni, Prisniparni, } \\
\text { Khadira, Devdaru etc. }\end{array}$ & $\begin{array}{l}\text { Vatvikar, convaleescence, general } \\
\text { debility, loss of appetite. }\end{array}$ \\
\hline
\end{tabular}

\section{Determination of $\mathrm{pH}$}

The potential of hydrogen $\left(\mathrm{p}^{\mathrm{H}}\right)$ is a numeric scale normally used to denote the basicity or acidity. The $\mathrm{P}^{\mathrm{H}}$ values for each preparation were determined by using digital $\mathrm{P}^{\mathrm{H}}$ meter ${ }^{10,11}$.

\section{Determinations of total solid content}

This method is performed to get information of total solid content present in the preparation ${ }^{6,12}$. The preparation of Asava and Arishta's were taken in pre weighed petri dishes $10 \mathrm{ml}$ of each and dried under oven. The total solid content was calculated on percentage weight by $\mathrm{ml}$ basis.

Weight of empty Petri dishes $=$ w1

Weight of Petri dish + sample $=w 2$

Solid content $=\mathrm{w} 3=\mathrm{w} 2-\mathrm{w} 1$

Percentage total solid content $=\mathrm{w} 3 / 10 * 100$

\section{Determination of density}

Density determination by pycnometer is a very precise method. In the present study density of the sample was determined ${ }^{13}$.

\section{Determination viscosity}

The viscosity of liquid is measure of its frictional resistance. in the present study viscosity of all the samples was determined by using Oswald's viscometer ${ }^{14,15}$.

\section{Determination surface tension}

The formed drops flow freely from the capillary, is reliant on the surface tension of liquid. The surface tensions of all samples were determined by using stalagnometer ${ }^{14,15}$ (drops weight method).

\section{RESULT AND DISCUSSION}

The purity, quality and standard parameters for ayurvedic preparation should be established to have an edge over Allopathic, Unani, Chinese and other systems of medicine.

The comparative results of Vasakasavsav, Ushiraasav, Punarnasava, Ashokarishta, Dashmularishta and Khadirarishta for all test parameter like Preliminary evaluation given in Table 2 and determination of alcohol content, determination of $\mathrm{pH}$, determinations of total solid content, determination of density, determination viscosity and determination surface tension were given in Table 3.

Table 2: Preliminary evaluation study of Ayurvedic preparation

\begin{tabular}{|l|l|l|l|l|l|l|l|}
\hline Sr.no & Parameters & \multicolumn{3}{|c|}{ Asavas } & \multicolumn{3}{c|}{ Arishta's } \\
\hline & & Vasakasavsav & Ushiraasav & Punarnasava & Ashokarishta & Dashmularishta & Khadirarishta \\
\hline 1. & Colour & Brown & Dark brown & Dark brown & Blackish brown & Light brown & Dark brown \\
\hline 2. & Taste & Sweet and bitter & Bitter & Bitter & Sweet and astringent & Sweet & Bitter \\
\hline 3. & Odour & Aromatic & Pleasant & Pleasant & Aromatic & Pleasant & Aromatic \\
\hline
\end{tabular}

Table 3: Evaluation study of Ayurvedic preparation

\begin{tabular}{|l|l|l|l|l|l|l|l|}
\hline Sr.no. & \multicolumn{1}{|c|}{ Parameters } & \multicolumn{3}{|c|}{ Asavas } & \multicolumn{3}{c|}{ Arishta's } \\
\hline & & Vasakasavsav & Ushiraasav & Punarnasava & Ashokarishta & Dashmularishta & Khadirarishta \\
\hline $\mathbf{1}$ & Total alcohol content(\%v/v) & 10.2. & 8.55 & 9.54 & 10.03 & 1069 & 10.86 \\
\hline $\mathbf{2}$ & Ph determination & 4.87 & 5.02 & 4.91 & 4.65 & 5.11 & 4.68 \\
\hline $\mathbf{3}$ & Density & 1.093 & 1.053 & 1.034 & 1.088 & 1.012 & 0.996 \\
\hline $\mathbf{4}$ & Viscosity(Poise) & 2.6786 & 1.8606 & 1.9932 & 3.4852 & 3.4927 & 2.0704 \\
\hline $\mathbf{5}$ & Surface Tension(dynes/cm) & 90.0936 & 92.130 & 83.853 & 97.2778 & 78.613 & 68.47 \\
\hline $\mathbf{6}$ & $\begin{array}{l}\text { Determinations of total solid } \\
\text { content }\end{array}$ & $26 \% \mathrm{w} / \mathrm{v}$ & $8 \% \mathrm{w} / \mathrm{v}$ & $12 \% \mathrm{w} / \mathrm{v}$ & $18 \% \mathrm{w} / \mathrm{v}$ & $28 \% \mathrm{w} / \mathrm{v}$ & $45 \% \mathrm{w} / \mathrm{v}$ \\
\hline
\end{tabular}




\section{ACKNOWLEDGEMENT}

The authors are thankful to the Prof. S. N. Dhole (Principal Modern College of Pharmacy (Ladies), Moshi, Pune and Prof. P. D. Chaudhari (Principal Modern College of Pharmacy, Nigdi, Pune) for providing facilities to carry out this work.

\section{REFERENCES}

1. Mukharjee PK and Wahile A. Integrated approaches towards drug development from Ayurveda and other Indian system of medicines. Journal of Ethnopharmacology 2006; 103 (1):25-35.

2. Anonyms, The Indian Pharmacopoeia, $3^{\text {rd }}$ ed, Controller of publications, Delhi, 1985.

3. Mishra LC. Scientific Basis for Ayurvedic Therapies, CRC Press; 2004.

4. Trease and Evans. Pharmacognocy, $15^{\text {th }}$ ed, Saunder, Edinburgh, London, New York. 2002.

5. Vyas M, Shukla VJ, Patgiri BJ, Prajapati PK. A unique concentrated and fermented dosage form i. e. Pravahi kwatha. International Journal of Pharmaceutical Archive 2010; 1(3):287-290.

6. Pathak A, Khushwah S, Dhongade H, and Nayak S. Preliminary Evaluation of Some Ayurvedic Preparations of Asava and Arishta's. International Journal of Biological Sciences 2008; 2(3):149-152.

7. Weerasooriya WMB, Liyanage JA and Pandya SS. Qualitative parameter of different preparations of asava and Arishta's used in ayurvedic medicines: An assessment. Indian Journal of Pharmacology 2006; 38(5):365.

8. Rangari VD. Pharmacognosy and Phytochemistry, $1^{\text {st }}$ ed, part 1, Career publications; 2004.
9. Selvan PS and Sanmuga PE. Determination of Ethanol Content in Ayurvedic Formulations Kumaryasava and Mustakarista by Gas Chromatography. Indian Journal of Pharmaceutical Sciences 2015;120-125.

10. Chatwal. GR., Anand SK. Instrumental Methods of Chemical Analysis. $5^{\text {th }}$ ed, Himalaya Publishing House; 2005.

11. Sayyad SF, Randive DS, Jagtap SM, Chaudhari SR and Panda BP. Preparation and evaluation of fermented Ayurvedic formulation: Arjunarishta. Journal of Applied Pharmaceutical Science 2012; 2(05):122-124.

12. Chumbhale DS, Chaudhari SR and Upasani CD. Standardization of marketed kumari asava- a polyherbal ayurvedic formulation. International Journal of Pharmaceutical, Chemical and Biological Sciences 2014; 4(3):681-685.

13. Anonyms, Government of India, Ministry of Health \& Family Welfare. Indian Pharmacopoeia. Vol II (P-Z), Controller of publications, Delhi, 1996. p. A- 8.15, 99.

14. Hadkar UB. A Handbook of Practical Physical Pharmacy and Physical Pharmaceutics, 4 ${ }^{\text {th }}$ ed, Nirali Prakashan; 2007.

15. Tekeshwar K, Larokar YK, Jain V. Standardization of different marketed brands of Ashokarishta: An Ayurvedic formulation. Journal of Scientific and Innovative Research 2013; 2 (6): 993-998.

\section{Cite this article as:}

Mohini Kuchekar et al. Preliminary studies of some marketed Ayurvedic preparations of Asava's and Arishta's. Int. Res. J. Pharm. 2017;8(8):18-20 http://dx.doi.org/10.7897/22308407.088138

Disclaimer: IRJP is solely owned by Moksha Publishing House - A non-profit publishing house, dedicated to publish quality research, while every effort has been taken to verify the accuracy of the content published in our Journal. IRJP cannot accept any responsibility or liability for the site content and articles published. The views expressed in articles by our contributing authors are not necessarily those of IRJP editor or editorial board members. 